\title{
Public Awareness, Attitudes, and Adherence to COVID-19 Quarantine and Isolation in Saudi Arabia
}

\section{Mohammed Khamash \\ Almaghrabi $\mathbb{D}$}

Microbiology and clinical parasitology Department, College of Medicine, King Khalid university, Abha, Asir, Saudi Arabia
Correspondence: Mohammed Khamash Almaghrabi

Microbiology and clinical parasitology Department, College of Medicine, King Khalid University, Abha, Asir, Saudi Arabia Email malmaghrabi@kku.edu.sa
Background: This study aims to assess the general population's awareness, attitude, and adherence regarding COVID-19 and quarantine in Saudi Arabia.

Methods: A descriptive cross-sectional design with a consecutive sampling method was used in this study. All accessible Saudi population during the study period were invited to participate in the survey from 1st April to 25th April 2020. The study questionnaire was constructed by the researchers based on experts' consultation.

Results: A total sample of 1998 respondents with complete data was included in the survey. A total of 1936 participants reported that they were aware of regarding COVID-19 outbreak (96.9\%). The most identified symptom was fever $(92.3 \%$; 1843), followed by respiratory distress $(90.8 \%$; 1813). About $81 \%$ of the participants reported that quarantine should be applied with travel or contact with infected persons. Also, $98.3 \%$ of the participants reported that the quarantine period should be a minimum of 14 days. In total, more than three-quarters of the participants had good awareness levels regarding COVID-19 and quarantine.

Conclusion: This study showed that the Saudi population had very high levels of awareness, adherence regarding COVID-19 quarantine and isolation measures.

Keywords: attitude, awareness, coronavirus, isolation, quarantine

\section{Introduction}

World Health Organization (WHO), ${ }^{1}$ classified the coronavirus disease as an outbreak 2019-2020 (COVID-19) and considered it a public health emergency of international concern (PHEIC) on 30th January 2020, and a pandemic on 11th March 2020. ${ }^{2}$ Global health experts and South Asian governments expressed concerns related to the spread of COVID-19 and potential for more than 7.6 million deaths in South Asia if no action were taken. ${ }^{3}$ The learned lesion from the life-threatening Coronavirus disease (COVID-19) is the importance of support system, isolation, contact tracing, and functional testing in managing a pandemic. ${ }^{4}$ Fundamental to this multipronged strategy is observing quarantine and self-isolation as it has shown to be effective in reducing infection rates in a population by breaking the chain of transmission. ${ }^{5}$

The healthcare system of the third-world country has failed to address the challenges in providing medical care for the rising number of infected patients. In the majority of cases, the leadership seemed inefficient, unprepared, and indecisive. $^{6}$ The active participation of every human being has become essential to the containment of COVID-19 since this enables hospitals to effectively mitigate the issue through preventive measures such as; social distancing, self-quarantine, and personal hygiene. ${ }^{7}$ 
To avert the rapid transmission of disease, the influence of quarantine has been significantly emphasized and is considered the most important goal to minimize COVID19 spread. It is generally applied in the form of restriction of movement or isolation from the rest of the population of healthy persons who may have been exposed to the virus and for assessment of their symptoms and detection of early cases. ${ }^{8}$ Many countries have the legal authority to impose quarantine. Quarantine should be implemented as a part of a comprehensive package of public health standards and containment measures and following International Health Regulations considering undertaking the dignity, human rights, and fundamental freedoms of persons. ${ }^{9}$

Activities to achieve this objective differ and are based on national risk evaluations that include the availability of hospital beds, ventilation support, and numbers of patients requiring hospitalization. ${ }^{10}$ Varying levels of contact tracing are included in the majority of national response strategies along with the promotion of public health measures such as respiratory etiquette, social distancing, handwashing, and preparation of health systems for a surge of extremely ill patients needing oxygen, mechanical ventilation, isolation, and strengthening health facility infection prevention and control. ${ }^{11}$

Personal hygiene and public health practices such as handwashing and physical distancing are important in the quarantine of suspected or confirmed cases to minimize coronavirus spread. ${ }^{12}$ However, it will be challenging to adhere to these practices in many cities and rural areas, especially in developing countries. ${ }^{13}$ Without sustained bans on large gatherings such as culture-related behaviors and faith practices including mass prayer gatherings, large weddings, and funerals, these cases may create superspreading events with accelerated transmission. ${ }^{14}$

Zhong et $\mathrm{al}^{15}$ have revealed that attitudes towards government measures were highly associated with the level of knowledge regarding COVID-19 and indicated that individuals would maintain a positive attitude towards COVID-19 preventive practices based on higher education and information level. Therefore, perception of risk would contribute to the adherence toward symptom prevention throughout global epidemics outbreaks. ${ }^{9,16}$ The type of information possessed by an individual can affect the risk of being infected by the coronavirus. The probability of this infection can be increased due to a lack of information or disinformation. What is interesting to consider is that individuals make decisions based on their perception of risk but not on the real risk. Indeed, it was identified that massive distress is potentially generated through psychological responses during the spread of the SARS epidemic. ${ }^{17}$ The determination of citizens for following government guidelines might be associated with knowledge of the infection process and its precautions regarding quarantine measures. Several studies have supported the same perspective, where it is witnessed that the knowledge level directly influences the perception of vulnerability to disease. ${ }^{18,19}$

On March 2nd, 2020, the Saudi Arabian Ministry of Health confirmed the first case of the COVID-19 disease caused by the SARS-CoV-2 virus in the Kingdom. As of 28th June 2021, the Saudi Government has reported 482,003 confirmed COVID-19 cases to the WHO, with 7760 deaths. ${ }^{20}$ Despite the mandatory nature of public protective measures, it is significant that the compliance to each of them is moderately adverse among the population. To some extent, the non-compliance and the disinterest of specific human groups are alarming concerning these regulations. The reinforcement of strategies for mitigating the deteriorating symptomatic cases and the close monitoring of the population in this social isolation stage becomes essential in the government's efforts. This phenomenon is identified by cross-sectional studies as an attitudinal issue linked with the population. , $^{9,15,16,21}$

Awareness programs have been initiated by the Ministry of Health (MOH) for educating the public regarding the virus mode of transmission and the significance of curfew. In addition, the $\mathrm{MOH}$ has applied strict measures for controlling the virus transmission, such as reducing social contacts, suspending schools, restricting outdoor activities, and banning mosques' prayers. However, it was assumed that understanding the transmission mode is a more instant need at this stage between humans. More emphasis is needed on public awareness to be imposed to stand against the pandemic. The current study, therefore, aims to assess Saudi population awareness, attitude, and practices towards quarantine and isolation during the outbreak of COVID-19.

\section{Materials and Methods Design}

A descriptive cross-sectional design with a consecutive sampling method was used in this study. All accessible Saudi population during the study period were invited to participate in the survey. After obtaining permission from 
the Institutional ethics committee, data were collected from participants who agreed to fill the online pre-structured questionnaire. Informed consent was obtained before commencing the survey. Participants were assured that their responses would be confidential and confirmed that their participation was voluntary in the survey. Their knowledge was assessed against facts published by WHO. This study was conducted in accordance with the principles of the Declaration of Helsinki proposed by the World Medical Association for the protection of human subjects in research.

\section{Instrument}

The study questionnaire was constructed by the researchers based on experts' consultation and intensive literature review. $^{22}$ The questionnaire was uploaded online from $1 \mathrm{st}$ April to 25th April 2020 by the researcher.

The first section of the questionnaire included participant's personal data such as age, gender, educational level, monthly income, and having health care workers in the family. The second section covered awareness questions (n =9) toward quarantine and isolation, including signs and symptoms, transmission methods, quarantine definition and types, and precautions needed to prevent disease transmission. Each question was based on a different response scale, and the participant can select multiple options to answer these questions. The attitude and practice of the participants toward quarantine and isolation were assessed in the third part of the instrument. For instance, information on disease risk in the community was answered through a 4-point scale $(1=$ no risk, $2=$ low risk, 3 = intermediate-risk, and $4=$ high risk). Other questions such as quarantine are vital for those with symptoms, governmental rules of quarantine and lockdown are vital, and community culture achieves quarantine importance were measured on a 2 -point rating scale $(1=$ agree, 2 $=$ disagree).

A panel of 3 experts reviewed the instrument independently for content validity, and any modifications were applied after consensus till having the final format. A pilot test was conducted by including 25 participants for measuring reliability using the reliability test (Cronbach's Alpha $=0.79)$.

\section{Data Analysis}

After data were extracted, it was revised, coded, and imported into the statistical software IBM SPSS version 22 (SPSS, Inc. Chicago, IL). All statistical analyses were done using a two-tailed test. P-value less than 0.05 was considered to be statistically significant. For awareness items, each correct answer was scored one point, and the total summation of the discrete scores of the different items was calculated. A patient with a score less than $60 \%$ (8 points) of the maximum score was considered to have poor awareness, while good awareness was considered if he had a score of $60 \%$ ( 9 points or more) of the maximum or more. Descriptive analysis based on frequency and percent distribution was done for all variables, including demographic data, awareness items, and participant practice and attitude. Cross-tabulation was used to assess the distribution of awareness according to participants' personal data, and practice, and attitude. Relationships between variables were tested using the Pearson chi-square test.

\section{Results}

A total sample of 1998 respondents with complete data was included in the survey. Participants' ages ranged from 18 to 88 years with a mean age of $31.8 \pm 10.6$ years. Males were $1320(66.1 \%)$ of the respondents, and $1524(76.3 \%)$ were university graduated. A total of $48.8 \%$ of respondents were living with more than seven persons. Monthly income exceeding SAR 10,000 (2667 USD) was reported by 641 participants $(50.3 \%)$, and 841 participants had health care workers in their families (Table 1).

Table 2 illustrates participants' awareness regarding COVID-19 and quarantine. Out of 1998 participants, 1936 participants reported that they were aware of the COVID-19 outbreak (96.9\%). The most identified symptom was fever $(92.3 \%$; 1843), followed by respiratory distress $(90.8 \% ; 1813)$ and cough $(76 \% ; 1516)$. A total of $95.2 \%$ of the participants reported virus transmission through patient droplets and contaminated services. Home quarantine was correctly defined by 1852 (92.7\%) of the participants, and health quarantine was defined by 1977 participants (98.9\%).81\% of the participants reported that quarantine should be applied with travel or contact with infected persons. Also, $98.3 \%$ of the participants reported that the quarantine period should be a minimum of 14 days. Using a mask in case of having cough or caring infected person was reported by 1664 participants $(83.3 \%)$, and $73.9 \%$ of them correctly reported quarantine as non-adherent. In total, $1738(87 \%)$ of the participants had a good awareness level regarding COVID-19 and quarantine. 
Table I Personal Data of General Population Participants in Saudi Arabia

\begin{tabular}{|c|c|c|c|}
\hline Variables & & No & $\%$ \\
\hline \multirow[t]{4}{*}{ Age in years } & $<25$ years & 678 & $33.9 \%$ \\
\hline & $25-34$ & 594 & $29.7 \%$ \\
\hline & $35-44$ & 480 & $24.0 \%$ \\
\hline & $45-88$ & 246 & $12.3 \%$ \\
\hline \multirow[t]{2}{*}{ Gender } & Male & 1320 & $66.1 \%$ \\
\hline & Female & 678 & $33.9 \%$ \\
\hline \multirow[t]{4}{*}{ Educational level } & Basic education & 59 & $3.0 \%$ \\
\hline & Secondary & 415 & $20.8 \%$ \\
\hline & education & & \\
\hline & University/ more & 1524 & $76.3 \%$ \\
\hline \multirow[t]{3}{*}{ Marital status } & Single & 835 & $41.8 \%$ \\
\hline & Married & 1072 & $53.7 \%$ \\
\hline & Divorced/ widow & 91 & $4.6 \%$ \\
\hline \multirow[t]{2}{*}{ Family size } & $<7$ persons & 1022 & $51.2 \%$ \\
\hline & $>7$ persons & 976 & $48.8 \%$ \\
\hline \multirow[t]{8}{*}{ Monthly income } & $<3000$ SR $(<800$ & 164 & $8.2 \%$ \\
\hline & USD) & & \\
\hline & $3000-6000$ SR & 293 & $14.6 \%$ \\
\hline & (800-1600 USD) & & \\
\hline & $6000-10,000$ SR & 536 & $26.8 \%$ \\
\hline & (I600-2667 USD) & & \\
\hline & $>10,000 \mathrm{SR}$ & 1005 & $50.3 \%$ \\
\hline & (>2667 USD) & & \\
\hline \multirow[t]{2}{*}{ Have internet and use it } & Yes & 1922 & $96.2 \%$ \\
\hline & No & 76 & $3.8 \%$ \\
\hline \multirow{2}{*}{$\begin{array}{l}\text { Your family member working } \\
\text { in health-related field }\end{array}$} & Yes & 841 & $42.1 \%$ \\
\hline & No & 1157 & $57.9 \%$ \\
\hline
\end{tabular}

As for participants' practice, Table 3 demonstrates that $1869(93.5 \%)$ of the participants were at home with their families, and $89.1 \%$ stayed at home after return back from traveling. Finding alternative activities within the quarantine period was reported by 1407 participants (70.4\%).

Considering participants' attitudes (Table 4), 1510 (75.6\%) participants agreed that the disease had a high risk to the community. "Quarantine is vital for those with symptoms" was reported by $98.5 \%$ of the participants, and $99.1 \%$ of them agree with the governmental rules of quarantine and lockdown.

Table 5 illustrates the distribution of participants' awareness according to their characteristics, practice, and attitude. A total of $89.3 \%$ of male participants had a good awareness level compared to $82.4 \%$ of females with statistically significant difference $(\mathrm{P}=0.001)$. Also, a good awareness level was recorded for $88.6 \%$ of highly
Table 2 Participants' Awareness Regarding COVID-19 Outbreak and Quarantine

\begin{tabular}{|c|c|c|c|}
\hline \multicolumn{2}{|c|}{$\begin{array}{l}\text { Awareness Regarding COVID-19 and } \\
\text { Quarantine }\end{array}$} & \multirow{2}{*}{$\begin{array}{l}\text { No } \\
1936 \\
62\end{array}$} & \multirow{2}{*}{$\begin{array}{c}\% \\
96.9 \% \\
3.1 \%\end{array}$} \\
\hline $\begin{array}{l}\text { Awareness of COVID- } \\
19\end{array}$ & $\begin{array}{l}\text { Yes } \\
\text { No }\end{array}$ & & \\
\hline Signs \& Symptoms & $\begin{array}{l}\text { Fever } \\
\text { Cough } \\
\text { Respiratory stress } \\
\text { Sore throat } \\
\text { Headache } \\
\text { Congestion } \\
\text { Anosmia }\end{array}$ & $\begin{array}{l}1843 \\
1516 \\
1813 \\
1131 \\
13 \\
513 \\
24\end{array}$ & $\begin{array}{l}92.3 \% \\
76.0 \% \\
90.8 \% \\
56.7 \% \\
0.7 \% \\
25.7 \% \\
1.2 \%\end{array}$ \\
\hline $\begin{array}{l}\text { Method of getting } \\
\text { infection }\end{array}$ & $\begin{array}{l}\text { Patient droplets and } \\
\text { contaminated services } \\
\text { By air } \\
\text { By food }\end{array}$ & $\begin{array}{l}1903 \\
72 \\
23\end{array}$ & $\begin{array}{l}95.2 \% \\
3.6 \% \\
1.2 \%\end{array}$ \\
\hline $\begin{array}{l}\text { Awareness related to } \\
\text { home quarantine }\end{array}$ & $\begin{array}{l}\text { Incorrect answer } \\
\text { Correct answer }\end{array}$ & $\begin{array}{l}146 \\
1852\end{array}$ & $\begin{array}{l}7.3 \% \\
92.7 \%\end{array}$ \\
\hline $\begin{array}{l}\text { Awareness related to } \\
\text { health quarantine }\end{array}$ & $\begin{array}{l}\text { Incorrect answer } \\
\text { Correct answer }\end{array}$ & $\begin{array}{l}21 \\
1977\end{array}$ & $\begin{array}{l}1.1 \% \\
98.9 \%\end{array}$ \\
\hline When to be quarantined & $\begin{array}{l}\text { With travel or contact } \\
\text { with infected persons } \\
\text { All community members }\end{array}$ & $\begin{array}{l}1618 \\
380\end{array}$ & $\begin{array}{l}81.0 \% \\
19.0 \%\end{array}$ \\
\hline $\begin{array}{l}\text { Quarantine duration } \\
\text { according to } \mathrm{MOH} \text { rules }\end{array}$ & $\begin{array}{l}3 \text { days } \\
7 \text { days } \\
14 \text { days }\end{array}$ & $\begin{array}{l}18 \\
16 \\
1964\end{array}$ & $\begin{array}{l}0.9 \% \\
0.8 \% \\
98.3 \%\end{array}$ \\
\hline When to use mask & $\begin{array}{l}\text { Have cough/ caring } \\
\text { infected person } \\
\text { Outside home }\end{array}$ & $\begin{array}{l}1664 \\
334\end{array}$ & $\begin{array}{r}83.3 \% \\
16.7 \%\end{array}$ \\
\hline $\begin{array}{l}\text { Emergency numbers to } \\
\text { inform related to } \\
\text { quarantine }\end{array}$ & $\begin{array}{l}911 \\
999\end{array}$ & $\begin{array}{l}1476 \\
522\end{array}$ & $\begin{array}{l}73.9 \% \\
26.1 \%\end{array}$ \\
\hline Overall awareness level & $\begin{array}{l}\text { Non-Adherent } \\
\text { Good }\end{array}$ & $\begin{array}{l}260 \\
1738\end{array}$ & $\begin{array}{l}13 \% \\
87 \%\end{array}$ \\
\hline
\end{tabular}

Table 3 Participants' Practice During COVID-19 Outbreak and Quarantine

\begin{tabular}{|l|l|l|}
\hline Practice Items & No & $\%$ \\
\hline You or family member was abroad during the last 2 & 126 & $6.3 \%$ \\
weeks & & \\
If yes, stayed at home after return back & 98 & $89.1 \%$ \\
You and your family stay at home & 1869 & $93.5 \%$ \\
Had alternative activities within quarantine period & 1407 & $70.4 \%$ \\
\hline
\end{tabular}

educated participants compared to $71.2 \%$ of those with a basic level of education ( $\mathrm{P}=0.001) .90 .6 \%$ of those with high monthly income had a good awareness level 
Table 4 Participants' Attitude Towards COVID-19 Outbreak and Quarantine

\begin{tabular}{|l|l|c|l|}
\hline Attitude Items & & No & $\%$ \\
\hline Disease risk on community & No risk & 19 & $1.0 \%$ \\
& Low risk & 76 & $3.8 \%$ \\
& Intermediate & 393 & $19.7 \%$ \\
& risk & 1510 & $75.6 \%$ \\
\hline High risk & Agree & 1968 & $98.5 \%$ \\
\hline $\begin{array}{l}\text { Quarantine is vital for those with } \\
\text { symptoms }\end{array}$ & Disagree & 30 & $1.5 \%$ \\
\hline $\begin{array}{l}\text { Governmental rules of quarantine } \\
\text { and lockdown are vital }\end{array}$ & Agree & 1980 & $99.1 \%$ \\
\hline $\begin{array}{l}\text { Community culture is aware of } \\
\text { quarantine importance }\end{array}$ & Disagree & 18 & $0.9 \%$ \\
\hline
\end{tabular}

compared to $75.2 \%$ of those with monthly income below SAR 3000 (800 USD) $(\mathrm{P}=0.001)$. Good awareness was recorded among $87.5 \%$ of those who agree with governmental rules for lockdown compared to $27.8 \%$ of those who were against $(\mathrm{P}=0.001)$. Also, $87.5 \%$ of participants who stay at home had good awareness, while $79.8 \%$ of those did not $(\mathrm{P}=0.013)$.

\section{Discussion}

This study has assessed the awareness, attitude, and practices of the Saudi population with regard to COVID-19 and quarantine during the outbreak, given its prevalence in Saudi Arabia and the higher occurrence of individuals infected in Riyadh, Jeddah, Mecca, Medina, Dhahran, Dammam, Hafouf, Taif, Qatif, and Al-Khobar. The adherence of Saudis to public health policies and protective measures was limited even though these policies and measures were implemented in the last few months.

Community compliance with quarantine is not easy due to its drawbacks on mental and psychological health. The more knowledgeable population will make the matter easier. The study revealed that the majority of the participants $(96 \%)$ were aware of the outbreak and more than $90 \%$ were aware of the main symptoms and mode of transmission. Regarding quarantine, more than $90 \%$ of the participants were aware of the health and home quarantine and who should be quarantined. Regarding quarantine duration, more than $90 \%$ of the participants said that it should be a minimum of two weeks, but $16 \%$ of the participants think that they should wear a mask outside the home only. In particular, more than three-quarters of the participants had a good awareness level. Awareness regarding COVID-19 and quarantine was higher among males, those with high education and economic level, participants who agree to quarantine as a protective measure, and participants who had their information from healthcare-related sources.

As for participants' attitude and practice, the study revealed that most of the participants were adherent to post travel home isolation with their families. Besides that, they found alternative activities during their quarantine and lockdown period, which improves their compliance. Perception of the outbreak as a high-risk community disease was perceived by three-quarters of the sample, but the thing which is dangerous that nearly $5 \%$ of the participants classified the outbreak as being with no risk, or even low risk on community. Those participants, if effective, maybe the snowball for spreading this concept among others, especially those with borderline attitudes and partially refusing these strict rules.

The participants' gender, education level, and monthly income were significantly associated with the awareness level of participants. This finding is in line with another study conducted in Saudi Arabia. ${ }^{21}$ Individuals with higher levels of education were more knowledgeable as compared to other categories. In addition, better awareness was also positively correlated with increased incomes $(60 \%, p=$ 0.001 ). Other studies have found similar findings, in agreement with the present study as knowledge towards COVID-19 was significantly lower among lower-income and less-educated participants in Saudi Arabia, ${ }^{23}$ Egypt, ${ }^{24}$ China, ${ }^{15}$ USA, ${ }^{25}$ and Nepal. ${ }^{26}$

Governments should make efforts to increase awareness among society through different communication channels for improving the level of awareness of people towards pandemics. People with lower socioeconomic status may need subsequent channels to communicate information regarding the risk and prevention related to the virus despite the efforts made by the $\mathrm{MOH}$ in offering educational information regarding COVID-19. This can be fulfilled through suggested strategies that emphasize attracting the attention of this segment of the population in the most frequently visited places such as grocery stores and shopping malls. The better practice was observed amongst the $<25$ age group compared to the $45-88$ age group, which could be demonstrated by the increased usage of different social media channels compared to the older group. It is essential to educate susceptible populations to expand their horizon of the disease cycle and to 
Table 5 Distribution of Participants' Awareness Level by Their Personal Data, Attitude and Practice

\begin{tabular}{|c|c|c|c|c|c|c|}
\hline \multicolumn{2}{|l|}{ Factors } & \multicolumn{4}{|c|}{ Awareness Level } & \multirow{3}{*}{ P-value } \\
\hline & & \multicolumn{2}{|c|}{ Poor } & \multicolumn{2}{|c|}{ Good } & \\
\hline & & \multirow{2}{*}{$\begin{array}{l}\text { No } \\
88\end{array}$} & \multirow{2}{*}{$\frac{\%}{13.0 \%}$} & \multirow{2}{*}{$\begin{array}{l}\text { No } \\
590\end{array}$} & \multirow{2}{*}{$\begin{array}{l}\% \\
87.0 \%\end{array}$} & \\
\hline Age in years & $<25$ years & & & & & \\
\hline & $25-34$ & 83 & $14.0 \%$ & 511 & $86.0 \%$ & \\
\hline & $35-44$ & 63 & $13.1 \%$ & 417 & $86.9 \%$ & \\
\hline & $45-88$ & 26 & $10.6 \%$ & 220 & $89.4 \%$ & \\
\hline \multirow[t]{2}{*}{ Gender } & Male & $|4|$ & $10.7 \%$ & 1179 & $89.3 \%$ & $0.001 *$ \\
\hline & Female & 119 & $17.6 \%$ & 559 & $82.4 \%$ & \\
\hline \multirow[t]{3}{*}{ Educational level } & Basic education & 17 & $28.8 \%$ & 42 & $71.2 \%$ & $0.001 *$ \\
\hline & Secondary education & 70 & $16.9 \%$ & 345 & $83.1 \%$ & \\
\hline & University/ more & 173 & $11.4 \%$ & $|35|$ & $88.6 \%$ & \\
\hline \multirow[t]{3}{*}{ Marital status } & Single & 107 & $12.8 \%$ & 728 & $87.2 \%$ & 0.922 \\
\hline & Married & 140 & $13.1 \%$ & 932 & $86.9 \%$ & \\
\hline & Divorced/ widow & 13 & $14.3 \%$ & 78 & $85.7 \%$ & \\
\hline \multirow[t]{2}{*}{ Family size } & $<7$ persons & 129 & $12.6 \%$ & 893 & $87.4 \%$ & 0.595 \\
\hline & $>7$ persons & $13 \mid$ & $13.4 \%$ & 845 & $86.6 \%$ & \\
\hline \multirow[t]{4}{*}{ Monthly income } & $<3000$ SR $(<800$ USD $)$ & 26 & $24.8 \%$ & 79 & $75.2 \%$ & $0.001 *$ \\
\hline & $3000-6000$ SR (800-1600 USD) & 27 & $14.5 \%$ & 159 & $85.5 \%$ & \\
\hline & 6000-10,000 SR (1600-2667 USD) & 53 & $15.5 \%$ & 289 & $84.5 \%$ & \\
\hline & $>10,000$ SR (>2667 USD) & 60 & $9.4 \%$ & 581 & $90.6 \%$ & \\
\hline \multirow[t]{2}{*}{ You or family member working in health-related field } & Yes & 101 & $12.0 \%$ & 740 & $88.0 \%$ & 0.256 \\
\hline & No & 159 & $13.7 \%$ & 998 & $86.3 \%$ & \\
\hline \multirow[t]{2}{*}{ Governmental rules of quarantine and lockdown are vital } & Agree & 247 & $12.5 \%$ & 1733 & $87.5 \%$ & $0.00 I^{*}$ \\
\hline & Disagree & 13 & $72.2 \%$ & 5 & $27.8 \%$ & \\
\hline \multirow[t]{2}{*}{ You and your family stay at home } & Yes & 234 & $12.5 \%$ & 1635 & $87.5 \%$ & $0.013^{*}$ \\
\hline & No & 26 & $20.2 \%$ & 103 & $79.8 \%$ & \\
\hline \multirow[t]{7}{*}{ Source of information } & Social media & 198 & $11.8 \%$ & 1479 & $88.2 \%$ & $0.001 *$ \\
\hline & Mass media & 96 & $9.7 \%$ & 898 & $90.3 \%$ & \\
\hline & $\mathrm{MOH} \& \mathrm{WHO}$ & 4 & $11.4 \%$ & 31 & $88.6 \%$ & \\
\hline & Health education posters & 0 & $0.0 \%$ & 3 & $100.0 \%$ & \\
\hline & Health care staff & 0 & $0.0 \%$ & 9 & $100.0 \%$ & \\
\hline & Internet & 8 & $53.3 \%$ & 7 & $46.7 \%$ & \\
\hline & Study/ work & 11 & $7.7 \%$ & 132 & $92.3 \%$ & \\
\hline
\end{tabular}

Note: P: Pearson $\mathrm{X} 2$ test. $* \mathrm{P}<0.05$ (significant).

enable the adoption of measures for preventing the spread of the disease.

It is clear that the implementation of quarantine will be only effective when individuals adhere to its compliance to prevent transmission at the community level. However, there are the majority of the limitations of such hypothetical consensus of quarantine adherence. ${ }^{6}$ Findings of the present study with respect to compliance of quarantine pre-requisites are higher as compared to the previous studies. ${ }^{27,28}$ Children who were quarantined at a center/ facility might be more vulnerable to mental health issues as compared to children who were quarantined at home due to their higher exposure and fear caused by parental separation.

As per the guidelines by the Ministry of Health of Saudi Arabia, irrespective of the lab results, people with COVID-19 symptoms should observe home isolation. ${ }^{29}$ Whereas, a person who have a contact history with 
a confirmed case and reports no symptoms is required to observe home quarantine for 14 days, irrespective of lab results. Those with mild symptoms are recommended to self-isolate at home for ten days, whereas those with severe symptoms should seek clinical care. Additionally, with symptomatic cases, it is mandatory not to leave selfisolation until three days after the disappearance of symptoms. ${ }^{29}$ Similarly, home quarantine and isolation have been suggested by other countries and health organizations. ${ }^{30-32}$ With the advent of COVID-19 vaccination, there have been some additions; as per guidelines by the Centers for Disease Control and Prevention, those who are fully vaccinated and show no symptoms do not need to quarantine if they come in contact with a confirmed case. ${ }^{30}$ As social media has a dominant role in spreading information among the masses, this can be used to tackle issue related to the hesitancy regarding vaccination and lack of trust. $^{33}$

Applying quarantine, physical distancing, and other measures early in an outbreak may reduce the spread of disease to a country or area or may delay the peak of an epidemic in an area where local transmission is ongoing, or both. However, if not implemented properly, quarantine may also create additional sources of contamination and dissemination of the disease. Those participants need to change community perception towards these socially annoying restrictions by improving their awareness regarding the current situation and potential hazards if there is no compliance with the rules besides the governmental penalties. It is imperative to promote and educate the masses regarding isolation and quarantine, as the burden of COVID-19 on hospitals and labs can lead to a diagnostic delay in other infectious diseases. ${ }^{34}$ In Europe, there are five key factors that were found most relevant in making people adhered to self-isolation, such as sufficient financial support, provision of alternative accommodation temporarily if required, accessible and clear communication by the public health department, effective contact tracing, and monitored adherence to self-isolation. ${ }^{32}$ Saudi Arabia can also strive for the provision of these factors that can help to minimize barriers related to self-isolation.

The study was limited to Riyadh, Jeddah, Mecca, Medina, Dhahran, Dammam, Hafouf, Taif, Qatif, and AlKhobar, Saudi Arabia. In addition, the number of females is less compared to male participants. The authors have indicated that lower female participation was due to the gender differences in response rate. Literature shows that gender influences online survey response behavior, although the authors attempt to equally distribute the survey via their personal and professional channels of social networks.

\section{Conclusions}

This study showed that the Saudi population had very high levels of awareness and adherence regarding COVID-19 quarantine and isolation measures. The participants were also aware of the significant role of quarantine and physical distancing in controlling the epidemic with flattening of the spread curve. Social and mass media had the most dominant role in the general population awareness, which should be properly used in the future by providing updated information using official sites to control the rumors and nonscientific or even non-confirmed facts.

Therefore, it is recommended that a structured and well-planned educational program should be undertaken to enhance the awareness level and contribute to better practice. People should follow the $\mathrm{MOH}$ instructions in this current pandemic and avoid close interactions with others, specifically immunocompromised individuals. In addition, washing hands often and strict personal hygiene measures are essential for controlling virus transmission. Also, the government should implement policies that can help in the removal of barriers related to self-isolation and quarantine. Baseline data can be provided by this population-based questionnaire to the government for preventive measures with respect to future outbreaks.

\section{Abbreviations}

COVID-19, Coronavirus Disease; WHO, World Health Organization; PHEIC, Public Health Emergency of International Concern; $\mathrm{MOH}$, Ministry of Health.

\section{Acknowledgments}

The author is thankful to all the associated personnel who contributed to this study by any means.

\section{Funding}

The authors are grateful to the Institute of Research and Consulting Studies (IRCS), KingKhalid University (KKU), Saudi Arabia for the financial support of this research throughthe grant number \# 4-N-20/21.

\section{Disclosure}

The author reports no conflicts of interest for this work. 


\section{References}

1. World Health Organization. Clinical management of severe acute respiratory infection (SARI) when COVID-19 disease is suspected; 2020. Accessed 16 April 2020.

2. Sohrabi C, Alsafi Z, O'Neill N. World Health Organization declares global emergency: a review of the 2019 novel coronavirus (COVID-19). Int J Surg. 2020;76:71-76. doi:10.1016/j.ijsu.2020.02.034.

3. Walker PG, Whittaker C, Watson O. The Global Impact of COVID-19 and Strategies for Mitigation and Suppression. WHO Collaborating Centre for Infectious Disease Modelling. MRC Centre for Global Infectious Disease Analysis, Abdul Latif Jameel Institute for Disease and Emergency Analytics, Imperial College London; 2020.

4. Sheikh A, Sheikh A, Sheikh Z, Dhami S, Sridhar D. What's the way out? Potential exit strategies from the COVID-19 lockdown. J Glob Health. 2020;10(1):010370. doi:10.7189/jogh.10.010370

5. Patel J, Fernandes G, Sridhar D. How can we improve self-isolation and quarantine for covid-19? BMJ. 2021;372:n625. doi:10.1136/bmj. n625

6. Saurabh K, Ranjan S. Preparedness, perceived impact and concerns of health care workers in a teaching hospital during coronavirus disease 2019 (COVID-19). J Family Med Prim Care. 2020;9 (8):4247. doi:10.4103/jfmpc.jfmpc_799_20

7. Bedford J, Enria D, Giesecke J, et al. COVID-19: towards controlling of a pandemic. Lancet. 2020;395(10229):1015-1018. doi:10.1016/ S0140-6736(20)30673-5

8. Zhang M, Zhou M, Tang F, et al. Knowledge, attitude and practice regarding COVID-19 among health care workers in Henan, China. J Hosp Infect. 2020;105(2):183-187. doi:10.1016/j.jhin.2020.04.012

9. Roy D, Tripathy S, Kar SK, Sharma N, Verma SK, Kaushal V. Study of knowledge, attitude, anxiety \& perceived mental healthcare need in Indian population during COVID-19 pandemic. Asian J Psychiatr. 2020;51:102083. doi:10.1016/j.ajp.2020.102083

10. World Health Organization. Critical preparedness, readiness and response actions for COVID-19; March 7, 2020. Available from: https://apps.who.int/iris/handle/10665/331422. Accessed March 13, 2020.

11. World Heath Organization. WHO virtual press conference on COVID-19; March 11, 2020. Available from: https://www.who.int/ docs/default-source/coronaviruse/transcripts/who-audio-emergenciescoronavirus-press-conference-full-and-final-11 mar2020.pdf?sfvrsn= cb432bb3_2. Accessed March 16, 2020.

12. Dahab M, Van Zandvoort K, Flasche S, et al. COVID-19 control in low-income settings and displaced populations: what can realistically be done. LSHTM. 2020;14(1):1-6.

13. Chen S, Yang J, Yang W, Wang C, Bärnighausen T. COVID-19 control in China during mass population movements at New Year. Lancet. 2020;395(10226):764-766. doi:10.1016/S0140-6736(20) 30421-9

14. Wong G, Liu W, Liu Y, Zhou B, Bi Y, Gao GF. MERS, SARS, and Ebola: the role of super-spreaders in infectious disease. Cell Host Microbe. 2015;18(4):398-401. doi:10.1016/j.chom.2015.09.013

15. Zhong BL, Luo W, Li HM, et al. Knowledge, attitudes, and practices towards COVID-19 among Chinese residents during the rapid rise period of the COVID-19 outbreak: a quick online cross-sectional survey. Int $J$ Biol Sci. 2020;16(10):1745-1752. doi:10.7150/ ijbs. 45221

16. Corrin T, Waddell L, Greig J, Young I, Hierlihy C, Mascarenhas M. Risk perceptions, attitudes, and knowledge of chikungunya among the public and health professionals: a systematic review. Trop Med Health. 2017:45(1);1-5. doi:10.1186/s41182-017-0061-x

17. Brooks SK, Webster RK, Smith LE, et al. The psychological impact of quarantine and how to reduce it: rapid review of the evidence. SSRN Electron J. 2020:395(10227):912-920.. doi:10.2139/ssrn.3532534
18. Chalya G, Chalya PL, Mbunda F. Knowledge, practice and factors associated with poor compliance with universal precautions among healthcare workers at Bugando Medical Centre, Mwanza, Tanzania. Tanzan J Health Res. 2016:18(3);1-10. doi:10.4314/ thrb.v18i2.3

19. Kong HK, Park TJ, Park KY. Knowledge on blood-borne infection, awareness and compliance on blood-borne infection control, and factors influencing compliance among emergency nurses. $J$ Healthc Assoc Infect Control Prev. 2016;21(2):65-73. doi:10.14192/ kjhaicp.2016.21.2.65

20. WHO Health Emergency Dashboard. WHO (COVID-19) Global; Saudi Arabia. Available from: https://covid19.who.int/region/emro/ country/sa. Accessed June 28, 2021.

21. Alahdal H, Basingab F, Alotaibi R. An analytical study on the awareness, attitude and practice during the COVID-19 pandemic in Riyadh, Saudi Arabia. J Infect Public Health. 2020:13(10);1-7. doi:10.1016/j.jiph.2020.06.015

22. Lake MA. What we know so far: COVID-19 current clinical knowledge and research. J Clin Med. 2020;20(2):124. doi:10.7861/ clinmed.2019-coron

23. Al-Mohrej A, Agha S. Are Saudi medical students aware of middle east respiratory syndrome coronavirus during an outbreak? $J$ Infect Public Health. 2017;10(4):388-395. doi:10.1016/j. jiph.2016.06.013

24. Abdel-hafiz AS, Mohammed Z, Ibrahim ME, et al. Knowledge, perceptions, and attitude of Egyptians towards the novel coronavirus disease (COVID-19). J Community Health. 2020;21:1. doi:10.1007/ s10900-020-00827-7

25. Wolf MS, Serper M, Opsasnick L, et al. Awareness, attitudes, and actions related to COVID-19 among adults with chronic conditions at the onset of the US outbreak: a cross-sectional survey. Ann Intern Med. 2020;173(2):100-109. doi:10.7326/M20-1239

26. Singh DR, Sunuwar DR, Karki K, Ghimire S, Shrestha N. Knowledge and perception towards universal safety precautions during early phase of the COVID-19 outbreak in Nepal. $J$ Community Health. 2020;45:1116-1122. doi:10.1007/s10900-020-00839-3.

27. Wang G, Zhang Y, Zhao J, Zhang J, Jiang F. Mitigate the effects of home confinement on children during the COVID-19 outbreak. Lancet. 2020;395(10228):945-947. doi:10.1016/s0140-6736(20) 30547-x

28. Paul A, Sikdar D, Hossain MM, et al. Knowledge, attitude and practice towards novel corona virus among bangladeshi people: implications for mitigation measures. medRxiv. 2020;15(9):1-30. doi:10.1101/2020.05.05.20091181

29. Ministry of Health. What do you need to know if you get infected with COVID-19?; July 28, 2020. Available from: https://covid19a wareness.sa/w p-content/uploads/2020/0 $7 /$ WhatToDoWhenGettingInfected.pdf. Accessed June 28, 2021.

30. CDC. When to quarantine; March 12, 2021. Available from: https:// www.cdc.gov/coronavirus/2019-ncov/if-you-are-sick/quarantine. html. Accessed June 28, 2021.

31. World Health Organization. Considerations for quarantine of contacts of COVID-19 cases; June 25, 2021. Available from: https://www. who.int/publications/i/item/WHO-2019-nCoV-IHR-Quarantine-2021. 1. Accessed June 20, 2021.

32. Patel J, Fernandes G, Sridhar D. Maximising public adherence to COVID-19 self-isolation in Europe. Lancet Regional Health Europe. 2021;4:100089. doi:10.1016/j.lanepe.2021.100089

33. Di Gennaro F, Murri R, Segala FV, et al. Attitudes towards anti-SARS-CoV2 vaccination among healthcare workers: results from a national survey in Italy. Viruses. 2021;13(3):371. doi:10.3390/v13030371

34. Di Gennaro F, Gualano G, Timelli L, et al. Increase in tuberculosis diagnostic delay during first wave of the COVID-19 pandemic: data from an Italian infectious disease referral hospital. Antibiotics. 2021;10(3):272. doi:10.3390/antibiotics10030272 


\section{Publish your work in this journal}

The International Journal of General Medicine is an international, peer-reviewed open-access journal that focuses on general and internal medicine, pathogenesis, epidemiology, diagnosis, monitoring and treatment protocols. The journal is characterized by the rapid reporting of reviews, original research and clinical studies across all disease areas. The manuscript management system is completely online and includes a very quick and fair peer-review system, which is all easy to use. Visit http://www.dovepress.com/ testimonials.php to read real quotes from published authors.

Submit your manuscript here: https://www.dovepress.com/international-journal-of-general-medicine-journal 